\title{
Integrity Risk in The Customs Automation System
}

\author{
Nik Hairi Omar, Mohd Nasir Selamat, Siti Fardaniah Abdul Aziz, Rusyda \\ Helma Mohd \& Rasyidah Ismail
}

To Link this Article: http://dx.doi.org/10.6007/IJARAFMS/v11-i3/10871 DOI:10.6007/IJARAFMS/v11-i3/10871

Received: 19 June 2021, Revised: 21 July 2021, Accepted: 08 August 2021

Published Online: 26 August 2021

In-Text Citation: (Omar et al., 2021)

To Cite this Article: Omar, N. H., Selamat, M. N., Aziz, S. F. A., Mohd, R. H., \& Ismail, R. (2021). Integrity Risk in The Customs Automation System. International Journal of Academic Research in Business and Social Sciences, 11(3), 206-222.

Copyright: (c) 2021 The Author(s)

Published by Human Resource Management Academic Research Society (www.hrmars.com)

This article is published under the Creative Commons Attribution (CC BY 4.0) license. Anyone may reproduce, distribute, translate and create derivative works of this article (for both commercial and non-commercial purposes), subject to full attribution to the original publication and authors. The full terms of this license may be seen at: http://creativecommons.org/licences/by/4.0/legalcode

\section{Vol. 11, No. 3, 2021, Pg. 206 - 222}

Full Terms \& Conditions of access and use can be found at http://hrmars.com/index.php/pages/detail/publication-ethics 


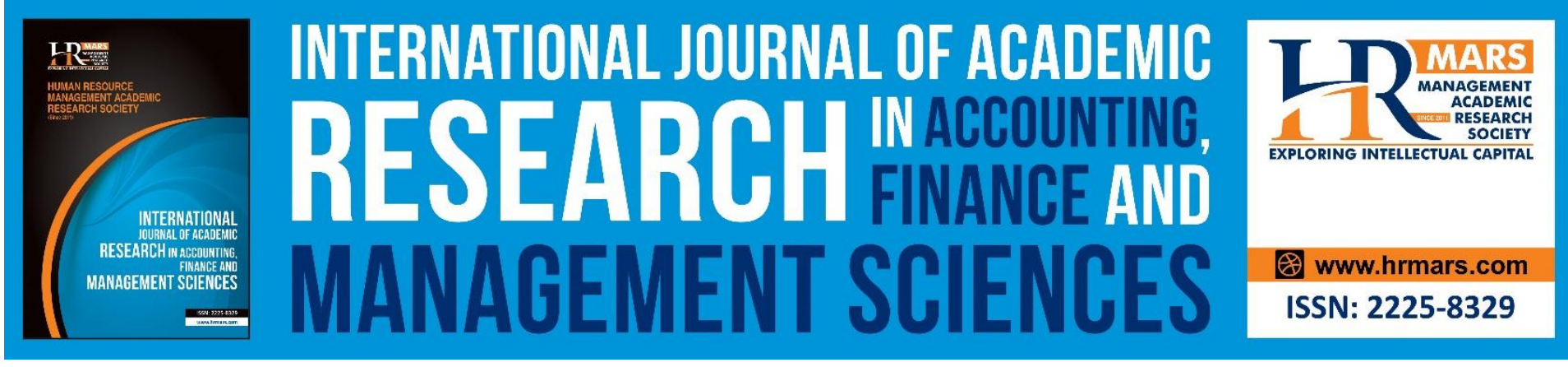

\title{
Integrity Risk in The Customs Automation System
}

\author{
Nik Hairi Omar ${ }^{1}$, Mohd Nasir Selamat ${ }^{2}$, Siti Fardaniah Abdul \\ Aziz $^{3}$, Rusyda Helma Mohd ${ }^{4}$, \& Rasyidah Ismail ${ }^{5}$ \\ 1,2,3,4 Human Development Program, Centre for Research in Psychology and Human Well- \\ being, Faculty of Social Science \& Humanities, Universiti Kebangsaan Malaysia, Malaysia, \\ ${ }^{5}$ Department of Integrity, Royal Malaysian Customs Department. \\ Email:md_nasir@ukm.edu.my, syeeda_1012@yahoo.com
}

\begin{abstract}
The major benefits of transforming the Customs manual system into automation is making data processing faster, reduce time delay and increase transparency for the international logistics management. A robust digital system of automation by default is assumed to be able to barricades any mistake made by parties involved in the process of declaration, assessing, and releasing goods from the Customs control. In this paper, we focused on the Integrity issues concerning the result of using the Customs Information System (CIS) in Malaysia as it is the only automation software used by The Royal Malaysian Customs for processing and releasing goods under its control. As a semi-digital system, CIS has its advantages and disadvantages that may affect integrity issues among Customs officials who administrated it. In this article, we used 795 samples of analytic data for imported prefabricated used vehicles (Toyota Wish) mined from CIS databank to examine whether this output data is administrated consistent, or otherwise, deteriorate with the requirements stipulated under the Customs importation rules and circulars in force? Our focus of analyses will be on the examination of how far the items in $\mathrm{K} 1$ electronic forms, namely tariff code declaration, vehicles first registration date, CIF value, imposed tax rates, physical check of vehicles and approval permit is consistent with the Customs Taxation law and Circulars. The finding shows that many output data are inconsistent with the current tax laws and circulars in force. These include $28.05 \%$ inaccurate samples for tariff code declaration, $80.63 \%$ that are not declared the vehicles first registration date in the origin country, and $98.62 \%$ are declared false or wrong CIF values. We found that $\mathrm{CIS}$ also failed to include the detailed records of vehicles year's made, VIN, seating capacity and the engine type as required by K-1 form. The output data also shows that there are $3 \%$ of samples charged with an inaccurate excise duty rate for different types of vehicles models or variants. In the physical inspection records, data showed that $100 \%$ of prefabricated vehicles brought in were not marked as inspected via CIS module. Meanwhile, for AP records, $73.21 \%$ of samples do not have valid approved permits and were classified as Record Not Found (RNF), while 7.05\% have expired AP. This evidence shows that $\mathrm{CIS}$ is a weak automation software and can be manipulated by the parties involved in the transaction process, either Customs officials or company agents. The main disadvantage is the design of the software that permit users to input value that may be incorrect, inaccurate,
\end{abstract}


or incomplete into the digital K-1 forms. As a semi-digital automation system, $\mathrm{CIS}$ does not integrate itself with multiple other government agencies (OGA), PIAs (permit Issuing Agencies) and other related bodies which also contribute to the failure to record, review, and validate transaction information quickly and correctly, such as information regarding approval permit and tax setting. It is suggested that CIS must be updated. The software must be able to prevent or block any incorrect, incomplete, or blank data entry into the system and must be able to warn users in the transaction process. The CIS must also be constructed to rejecting any data submission into the next levels of processing if the information is found inaccurate, incomplete, or blank. Apart from this, an education to CIS's customers especially to the importers and company agents must also be carried out properly.

Keywords: Integrity Risk, Digital Custom Automation System, Data Analytic, Custom Information System, Customs Agent, Customs Officials

\section{Introduction}

Customs Automation System (CAS) is the application of Information and Communication Technologies (ICT) for accomplishing the mission of Customs (WCO, 2016). The use of digital technology in the CAS project may support the entire or part of the total clearance process for releasing Customs goods. These include the submission and processing of electronic declaration forms, management of cargo acceptance, transit or logistics, inspection and verification of goods and the payment of duties and taxes (UNECE-TFIG, 2020). The sophistication of computer engineering in the CAS project will ease the conventional role of Customs officials in monitoring and supervising the process flows, validating results, and releasing goods from Customs control (OECD, 2005: p.4; Iñaki, 2014).

The major benefits of transforming the Customs manual system into automation is making data processing faster, reduce time delay and increase transparency (Razmerita \& BjørnAndersen, 2007; UNECE-TFIG, 2020). Less face-to-face interaction between taxpayers and Customs officials can reduce the opportunity for both sides to get engaged in corrupt practices, thus create trust, and encourages greater accountability among the parties (Pashev, 2005; OECD, 2005; Purohit, 2007; ITC, 2018). In the Fourth Industrial Revolutions (41R) era, the advancement in the Customs automation system may offer new possibilities for Customs administrations to manage pre-arrival processing, the automated release of securities and guarantees, and facilitating data collection for reporting the risks of management, external trade statistics and auditing purposes (UNECE-TFIG, 2020).

Due to its capabilities to manage large scale of trade volumes with simplifying Customs procedures and standardization of declarations forms, the CAS project was encouraged to be implemented by WCO to all its country members since First Kyoto Convention in 1973. As a result, there are many countries able to increase their performance in logistics management for international trade. One of the successful countries is Luxemburg via its eDuone project which was able to shift the country's Logistics Performance Index from 15th place in the year 2007 to 1st place in 2010 (WCO Report, 2017-2018).

However, build a high-quality, smart, and integrated Customs automation system that is connected to multiples Other Government Agencies (OGA) instead of having a fully automatic synchronization functionality as well as backup, updated and ease of use is not easy. The main difficulties are skills in analytical and project management to properly specify and manage user and technical requirements. It also requires developing and measuring achievable implementation and roll-out plans to keep the overall project on track (UNECE-TFIG, 2020). In many countries, the difficulties have resulted failures of providing a fully digital and 
MANAGEMENT SCIENCES

Vol. 11, No. 3, 2021, E-ISSN: 2225-8329 @ 2021 HRMARS

integrated CAS. Throughout the world, only 50\% of the countries use a fully automated and Integrated National Single Windows System (NSWS). Among them are Hong Kong China, Mali, Morocco, Honduras, Senegal, Chile, Burkina Faso, Australia, Iceland, New Zealand, USA, Switzerland, and Turkey (WTO TPR, 2015; UNECE-TFIG, 2020).

For some countries, the difficulties faced are a long process and resulted in a few stages of the CAS implementation. Malaysia for example was used a paper-based system before the year 1993. The system was then replaced with semi-digital automation called Custom Information System (CIS) in 1993 and updated time by time to be used until now. However, since 1997, Malaysia had developed the new NSWS project to replaced CIS, called as UCustoms. This third stage of Customs automation advancement, however not been ready to be implemented for quite years due to difficulties related to the issues of technical and analytical skills, projects management, and OGA integration (RMCD 2017). Only in early 2019, the UCustoms was launch as a pilot test in Lembah Klang, Sabah and Sarawak following strong pressure by the government of Malaysia to combat bribery among Customs officials under the second time of Mahathir leadership's (Sani, 2019).

During the stages of development, the implementation of CIS as a semi-digital Customs automation system might lead to issues of system fragility and serious breach of integrity among Customs officials. The semi-digital automation means that manual intervention and face-to-face over the counter touchpoints between clients and Customs officials concerning shipment, goods and the payment of duties and taxes still exist, thus creating an opportunity for corrupt practices to happen (UNECE-TFIG, 2020; Purohit, 2007; Pashev, 2005; Alon \& Hageman; Acconcia, D'Amato \& Martina, 2003; Aman et al., 2013, 2016). A weak Semi-digital automation system in terms of software's ability, hardware protocols, data flow management, and OGA integration provide space for incompetent or corrupt officials to be involved in the internal data manipulation such as inputting, altering, or approving values contradict with the requirement under the Customs Rules and Circulars in force. These may include values of tariff code, Cost-Insurance-Freight (CIF), date and time of physical checks and inspection, approve permit validity, and the value of tax and duties. Therefore, the integrity risks in the Customs automation system need to be studied for further improvement. In this paper, we concern about the issues of integrity breach and corruption among Customs officials in the Malaysian case by examining the process of how Custom Information System (CIS) is governed as reputable CAS. Our paper will focus on the specific case of the management flows of CIS for processing one of the Customs goods that is an imported vehicle (prefabricated private car) for the year 2017.

\section{Research Problem}

The issue of integrity breach among Malaysian Customs officials is an indisputable fact which can be seen in the Auditor General's Report (LKAN) every year. For example, in the year 2014, the LKAN's Report had given a serious warning to Royal Malaysian Customs Department (RMCD) concerning the shortage and overrate of charges in tax assessment activities. This warning was given at the suggestion of the National Audit Department (NAD) following audit findings for duty and tax assessment for the prefabricated used imported vehicles throughout Malaysia which concisely tells that:

"...the duty or tax assessment were not carried out properly and accurately, where $5.4 \%$ of the audit sample contain assessment errors, resulted in a shortfall in duty or tax collection amounting to RM1.29 million, and a surplus collection amounting to RM499,296. In addition, $2.8 \%$ of the audit samples were in poor quality forms of declaration which do not have clear 
MANAGEMENT SCIENCES

Vol. 11, No. 3, 2021, E-ISSN: 2225-8329 @ 2021 HRMARS

and detailed vehicles information. This caused the Auditor not able to confirm the import duty or tax amounting to RM1.85 million, and the value of the vehicles amounting to RM2.86 million" (LKAN, 2014, Series 3: p.121).

Although the report stressed that the duty and tax assessment was not carried out properly along with the facts of poor-quality declaration forms as well as shortage and surplus in the duty/tax collection, it does not provide the information on how the CIS is working. The report focused more on the paper-based records rather than the electronic system that uses to process the declaration forms and other steps of releasing Customs goods. Therefore, the attention of this paper is to analyze the extent to which the risk of integrity breach among Customs officials occurs in the management of electronic forms and other processes related to the declaration and releasing of imported prefabricated used vehicles via CIS as a sole CAS platform.

In general, the process of importing used passenger vehicles in Malaysia requires the Approval Permit (AP) from the Malaysian Industrial and Trade Investment (MITI). Only companies that have an AP are allowed to import the vehicle and it must be managed by a third-party company that provides an agent to deal with the Customs office (NAP2020-MITI, 2020). Meanwhile, the process of release and clearance of Customs goods is following the global standard as follows: (1) Declaration of carrier cargo to Customs office; (2) Arrival and temporary storage at the Customs Warehouse; (3) Preparation and submission of an electronic declaration form (K1 form) via CIS platform by clients (customs agent); (4) Validation of K1 electronic declaration forms by Customs Officials, (5) Physical inspection of vehicles at the warehouse by both parties, (6) Inspection results (pass, need further particulars, or failed); (7) Determination of duty and tax rates (8) Release /detent of vehicles (Ismail, 2019; World Bank, 2006).

Our focus on this article is on the 4th to 6th steps in the process of clearance of Customs goods, namely on the aspect of processing digital K1 forms via the CIS platform until it is approved and the good is released. It is expected that there are weaknesses in the management flow due to lack of knowledge and skills among officials, or breach of Integrity in the process of handling $\mathrm{K} 1$ forms especially related to the pledging of vehicle tariff code (i.e., vehicle type, use of class, and cubic capacity) and the determination of Customs value or CIF (Cost, Insurance, Freight) based on the gazetted price (Ismail, 2019; Angsor \& Yusof, 2019). Following the Customs Duty Order (2017), Excise Duty Order (2017) and Goods and Services Tax Order (2014), the determination of Customs value (i.e., CIF) is an important key for deciding tax and excise duties rate, thus requires information of vehicle chassis number, year of manufacture and date of first registration in the origin country. As reported in LKAN's 2014, the poor quality of the declaration forms is mostly related to the lack of vehicles data information that later affects shortage, surplus and unconfirmed import duties, and excise tax collection.

Therefore, the general question studied in this article is how CIS works in the process of entry, transmission, receiving and processing of Customs electronics form (K1 form) from the Customs agent to the Customs Officials until it will be processed, and the declared goods are released? Since the question is about the robustness of CIS, our focus of analyses will be on the examination of how far the item in $\mathrm{K} 1$ electronic forms (i.e., tariff code, vehicles first registration date, CIF value, imposed tax rates, physical check of vehicles and approval permit) which declared by agents are inspected and approved by Customs officials in accordance to the Customs Taxation law and circulars in force. A robust digital system of CAS by default is 
MANAGEMENT SCIENCES

Vol. 11, No. 3, 2021, E-ISSN: 2225-8329 @ 2021 HRMARS

assumed to be able to barricades any mistake or misuse that may be made by both parties during the process of declaration, assessing and releasing Customs goods. Another question to analyze is what are the major weaknesses that can be found in the use of CIS?

\section{Literature Review}

There are many studies related to the use and advantages of using CAS, as well as integrity risks relates to security, corruption and system. However, in-depth studies on CAS models, protocols and workflow, software abilities, parameters and databank output monitoring, and system audits are very limited to find. In this article, some relevant studies will be reviewed. Among are researched by The WTO- TPEEC, 2005; Razmerita \& Bjørn-Andersen, 2007; Nwankwo, 2017; McLinden \& Durrani, 2005; Crotty, 2010; Ferreira, Engelschalk \& Mayville, 2007 \& Ndonga, 2013.

Research by WTO-TPREC (2005) generally reveals that all OECD and non-OECD EC members have implemented Customs automation systems in their country. UNCTAD's ASYCUDA and ASYCUDA ++ are popular software installed in 62 out of 110 developing and least developed countries. In some countries, CAS is installed in major seaports, airports and across state borders. The study highlight that, the major challenges faced by EC non-EC members is the uniformity of implementation of the common Customs procedures due to variations in the availability of electronic access to Customs, limited interfaces for interoperability between systems, and different interpretations of EC customs legislation by national customs administrations.

Towards the implementation of Ubiquitous e-Custom Services, a study by Razmerita \& BjørnAndersen (2007) has concluded that major challenges faced by the modern e-customs systems are security threats, tax-related fraud, interoperability and simplified, and paperless trade transactions. However, future custom systems will be able to support simplified paperless trade procedures, prevent potential security threats and counterfeit tax-related fraud while at the same time ensure interoperability with other e-custom systems within and outside Europe. This research focus on the advantages of novel technologies for the implementation of advanced e-customs systems, particularly the use of service-oriented architecture (SOA), web services and TREC (Tamper Resistant Embedded Controller) device in an integrated framework named EPCIS (Electronic Product Code for Information Systems). Ndonga (2013) in his research on managing risks of corruption in NSWS review the use of Customs automation in the Philippines, Georgia and Qatar. One of the major challenges to resolve in the Philippines is complex bureaucratic procedures that require face-to-face interactions between importers and customs officers. Virtually all customs transactions in the Philippines since 1992 required clients to personally interact with officials. The introduction of ASYCUDA software in 1995, followed by parallel computerised customs-related activities such as the Project Abstract Secure (PAS) and Automated Customs Operating System (ACOS) was changed officials behaviour and reduce corruption practices. PAS require all payment of taxes and duties to be paid via a cashless channel to an Authorised Agent Bank (AAB) to avoid the opportunity for officials to abscond cash collections. While ACOS is a system used to facilitate the clearance of shipments by providing a digital assessment called SELECTIVITY which is able to categorise shipments into high, medium and low risk depending on their particulars. An experience faced by Georgia and Qatari Customs agencies is quite the same with the Philippines where numerous incidences of operators paying bribes to customs officials are happening in order to bring in goods without paying duty. Nonetheless, after 2003 the Georgian government made several modifications by introducing a one-stop-shop 
MANAGEMENT SCIENCES

Vol. 11, No. 3, 2021, E-ISSN: 2225-8329 ๔ 2021 HRMARS

system and Customs automated risk management that positively transformed the agency in logistics and corruptions index performance. The introduction of the Qatar Customs Clearance Single Window (QCCSW) in 2008 to replace a manual semi-paperless version of the ASYCUDA system and a documentary cycling program to govern its clearance process has also reduced corruption and promoted integrity in this country. The system essentially provides an electronic interface linking operators with relevant government agencies thereby facilitating customs clearance by integrating information on cargo manifest submission, cargo release modules, goods declaration, duties payment, pre-arrival details, inspection and postaudit clearance.

Nwankwo (2017) studied the development of NSW and Customs risk management in Nigeria. The country has started with AsyCuda++ software in 2006. According to him, the management of Electronic Document Interface (EDI) in the Computerised Risk Management System (CRMS) has become a centre for the risk management, governance and verification of electronic data, drafting and certification, pricing dan coding, valuation/classification and control. System integrity has been increased steadily where the CRMS and high capacity X-ray cargo scanning were linked and synchronised with the three Scanning Service and risk management service providers (SSPs), namely SGS, COTECNA Inspection, and Global Scan systems. (Nwankomo, 2017; p.735). According to Nwankwo, the output data of the AsyCuda++ system can be used for auditing purposes and able to identify risk and fraud trails. The study by Keen (2003), McLinden and Durrani (2005), and Crotty (2010) on the use of customs automation concluded that the use of automation can solve customs corruption issues. The introduction of automation provides the opportunity to implement standardized procedures that leave little to the discretion of the officials. Properly designed systems ensure that the correct rates of duties and taxes are applied; exemptions are only granted to authorized organizations and for authorized goods and services; the required information and documentation is presented; timeframes for payment are met, and those who do not comply with filing and payment timeframes are identified and follow-up action is taken. The automation system can also provide useful management information such as identifying transactions that do not meet time standards for processing or individual officers who undertake actions that are out of the ordinary (e.g., physically inspecting too many shipments).

Ferreira, Engelschalk and Mayville (2007) in their study on Customs automation and combating corruption argue that computerisation will not change customs monopoly in the matters of imports and exports. However, it will reduce discretion and increase levels of accountability. According to them, automation will affect officials' discretion in two ways. First, a well-designed system would streamline processes and substantially reduce face-toface contact between customs officials and clients. This would subsequently minimise opportunities for the inappropriate exercise of officials' discretion. Second, the introduction of computerised systems would also increase customs transparency by improving the accessibility of relevant information via online systems for the information related parties. It is concluded that automated systems would also cater for customs accountability by providing an electronic audit trail of all processes which can be relied on for future evaluation and review. This would force customs officials to follow the defined rules and procedures as any corrupt practices would be traceable through the system. 
MANAGEMENT SCIENCES

Vol. 11, No. 3, 2021, E-ISSN: 2225-8329 @ 2021 HRMARS

\section{Data and Methodology}

Data sources and components

We used analytic data mined from the CIS database using Crystal Report Tools for the years of 2017. Data analytics is the application of tests on information that is electronically available, either from the Enterprise's Resource Planning (ERP) systems or through brokers' databases and other digital sources (Arlyn, 2019; Jacentha \& Dalbir, 2020; Wahdain, Baharudin \& Ahmad, 2019). The analytical data obtained are particulars of K1 digital forms which is used for declaration and releasing of goods under Customs control. In this article, the goods referred to the used imported vehicles (i.e., prefabricated used cars), mostly from Japan. The particular of K1's form are filled by the Customs Agent (on behalf of the company/importers) and submitted to Custom authority via CIS platform for goods declaration and release purposes.

The application for this analytical data was made available to the Royal Malaysian Customs through Integrity Office for scientific observation in August 2019. The application was made in line with the National Anti-Corruption Campaign launched by the Prime Minister of Malaysia and the introduction of a pilot test for the new Ucustoms system to replace CIS in Westport, Port Klang (RMCD, 2019). Since output data is generated from CIS databank, the data integrity is not questionable because CIS was developed by Royal Malaysian Customs (RMCD) according to the International Standard (WCO 2006, RMCD 2017). The Customs agents submitted data via CIS following software's protocol set up accordingly to the requirement of Customs laws. The accuracy of the information entered by the Customs Agent is subject to Section 79 of the Customs Act 1967. Under this section, any fraudulent information entered by the Customs Agent for the goods declaration will be imposed such penalties. We obtained such data as in the examples of Figure-1 and Figure 2.

Figure -1 : The interface of digital K1 Registration Form in the Malaysian CIS

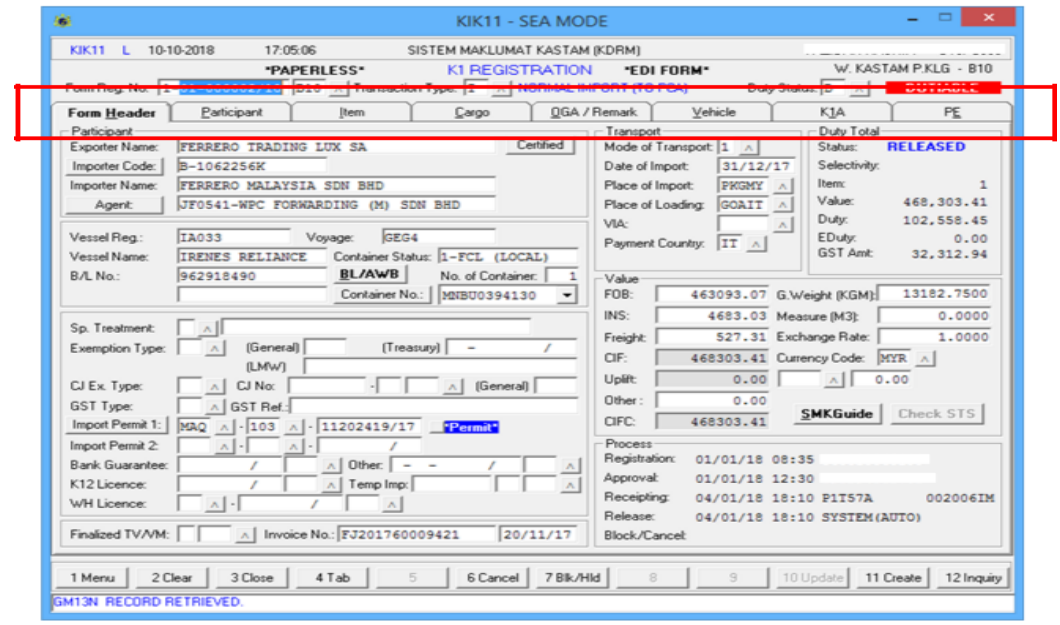

As shown in Figure-1, all information in the manual K1 registration form was adapted into digital K1 forms. Through the CIS interface, data was inputted in a few sections that are on the page of Form Header, Participants, Item, Cargo, OGA/Remark, Vehicle, KJA and PE. Each section has specific information required and need to be fulfilled by the Customs agent in the submission process. Figure- 2 in the next shows a final output data generated from K-1 Registration forms in the spreadsheet format. For this article, the data referred for analysis are the following:

(1) Vehicle tariff code (output data on vehicles type, class, and engine capacity). 
MANAGEMENT SCIENCES

Vol. 11, No. 3, 2021, E-ISSN: 2225-8329 @ 2021 HRMARS

(2) Custom value or Cost-Insurance-Freight or (CIF). Output data on chassis number, year of manufacture, and the first date of a vehicle registered in the origin country as a basis to calculate tax and excise duties).

(3) Data on Physical Checks (output data of date and time of checks, a tick records of inspection).

(4) Approve Permit (AP) (output data of validity, date of approval and expiring).

Figure -2: Output data of digital K1 Registration form in the spreadsheet

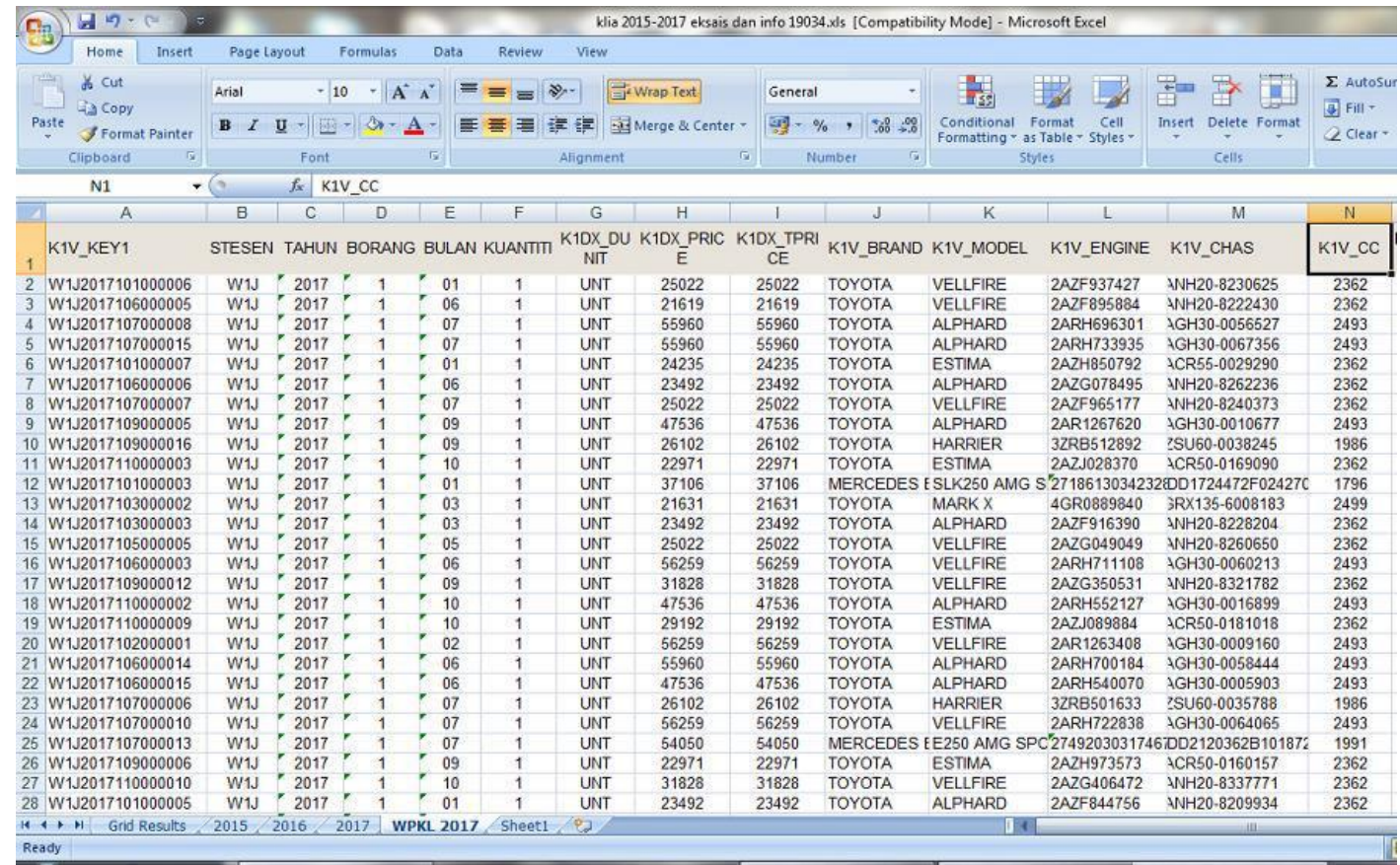

\section{Measuring output data consistencies}

The protocols for the importation of prefabricated used vehicles in Malaysia are based on the Customs Assessment Rules (1993), Customs Act (1967), and Customs Duty Order (2017), and related circulars (e.g., AP Import Guidelines and Vehicle inspection rules). Since the CIS is a semi-digital automation system, judging whether CIS has following integrity protocols or not is based on facts that all output data generated via CIS must be consistent with the Customs law and circulars as mentioned above. If the final output data is found to be inconsistent, it means that the software (CIS) has its weaknesses because it accepts the false or inaccurate value inputted by the Customs agent or Customs officials to be processed. This will later give a wrong continual effect on the next level of processing. For instance, wrong tariff code declaration in the $\mathrm{K} 1$ digital forms may later distort the information used in the classifications of vehicle body type, class, and engine capacity. In the next, it may later affect to wrong CIF declaration values where Cost-Insurance-Freight declaration is not based on the true year made of the vehicles and the date of first registration in the origin country instead of other particulars. In total, false, or inaccurate input data about this will be impacted on the calculation of tax rate and duty imposed on it. In general, it is a domino effect where a mistake at the beginning (or at any level) may lead to another mistake (s) in the next. In the end, the final effect is the loss of the true tax ratio which lead to the issues of shortage or overpaid tax collection. 
MANAGEMENT SCIENCES

Vol. 11, No. 3, 2021, E-ISSN: 2225-8329 @ 2021 HRMARS

\section{Population and Sample}

For the year 2017, a total of 8,531 prefabricated used imported vehicles were registered in the CIS database. The list of top five is Toyota (5,698 units), followed by Mercedez (1,280 units), BMW (261 units), Honda (260 units) and Land Rover (239 units). Meanwhile, 27 other vehicle models such as Lexus, Audi, Jaguar, Mini Cooper, Volkswagen, Maserati, Mclaren, Humer and Mitsubishi are relatively small.

In this article, we used only one vehicle model that is Toyota Wish (1.8cc and 2.0cc variants). The selection of this vehicle model has resulted from multi-stage random sampling from the list of 8,531 vehicles in the CIS database. In the first phase, selections were made to determine the most popular imported vehicle from the top five models that are Toyota, Mercedes, BMW, Honda, and Land Rover. At this stage, Toyota's model has been randomly selected. Subsequently, to narrow down the sample size from 5,698 Toyota's model, the second stage of selection were made by casting a simple random vote on the 16 different Toyota's model in which Toyota Wish was chosen (Table 1.0). In total there are 795 units of Toyota Wish models used as a sample (both 1.8 and $2.0 \mathrm{cc}$ variants).

Table 1.0: Multi-stage Random Sample selection

\begin{tabular}{rlr} 
No. & TOYOTA's Model & Number of K1 Form \\
\hline 1. & Vellfire & 2495 \\
2. & Estima & 980 \\
3. & Wish & 795 \\
4. & Alphard & 677 \\
5. & Harrier & 417 \\
6. & Land Cruiser Prado & 95 \\
7. & GT86 & 29 \\
8. & Mark-X & 16 \\
9. & FJ Cruiser & 37 \\
10. & Lain-lain model & 147 \\
11. & IQ & 4 \\
12. & Voxy & 2 \\
13. & Avensis & 1 \\
14. & RAV4 & 1 \\
15. & Spade & 1 \\
16. & Vanguard & 1 \\
\hline & TOTAL &
\end{tabular}

\section{Data Analysis}

We use simple descriptive statistics such as frequencies and percentages. Output data (samples) from CIS transformed into a specific scale according to the research objectives by creating a new code for nominal data, for example, the declarative code transformed into (1) True, and (2) False, or (1) Yes, and (2) No. Data transformation is carried out in various categories to classify the data output into right or wrong in conjunction with Customs and taxation laws in force. 
MANAGEMENT SCIENCES

Vol. 11, No. 3, 2021, E-ISSN: 2225-8329 @ 2021 HRMARS

\section{Finding and Discussion}

\section{Output consistencies with Custom taxation law and circular}

\section{a. Tariff Code Declaration}

Toyota Wish has two variants based on its cylinder capacities that are 1,798 cubic (less than $1.8 \mathrm{cc}$ ) and 2.0 cubic (more than 1.8, less than $2.0 \mathrm{cc}$ ). According to the Customs Duty Order (2017), the tariff code reference for Toyota Wish models is 8703237190 (for model less than $1.8 \mathrm{cc}$ ) and 8703237290 (for model $2.0 \mathrm{cc}$ ). A thorough inspection of 795 samples shows a sum of 11 different codes has been used to register Toyota Wish which involved 223 cars. As shown in Table 1.0, among code are 870321420 which refers to All-Terrain Vehicles (ATV); 870323521 - Corpse van with cylinder1.5cc and not less than 1.8cc; 870323531 - Prison van with $1.5 \mathrm{cc}$ cylinder and not less than $1.8 \mathrm{cc}$ and 870321909 - Other car types including station wagon and sports car less than 1.0cc; and 870323992 (this code no longer exists in Custom Duty Order 2017 and was used in the year of 2012-2015 only). According to Custom Duty Orders 2017, the real tariff code for Toyota Wish is fall under the header of "other vehicles including station wagons and sports cars, but not included van and 4WD which have cylinder capacity between $1.5 \mathrm{cc}$ and not more than $1.8 \mathrm{cc}$ (for tariff code 8703237190 or $1.8 \mathrm{cc}$ ) and between $1.8 \mathrm{cc}-2.0 \mathrm{cc}$ (for tariff code 8703237290 for $2.0 \mathrm{cc}$ )".

Table 1.0 - Analysis of True and False Tariff Code declaration under Custom Duty Orders $2017(n=795)$

\begin{tabular}{ccccccccc}
\hline \multirow{2}{*}{ Vehicles } & \multicolumn{3}{c}{ TRUE } & \multicolumn{3}{c}{ FALSE } \\
& \multicolumn{3}{c}{ Declaration } & \multicolumn{3}{c}{ Declaration (found on CIS) } & \multicolumn{2}{c}{ TOTAL (\%) } \\
\cline { 2 - 9 } & Tariff Code & Freq. & $\%$ & Tariff Code & Freq. & $\%$ & Freq. & $\%$ \\
\hline Wish 1.8cc & 8703237190 & 561 & 98.10 & 870323719 & - & - & 561 & 70.57 \\
Wish 1.8cc & 8703237190 & - & - & 870323991 & 199 & 25.03 & 199 & 25.03 \\
Wish 1.8cc & 8703237190 & - & - & 870360939 & 3 & 0.38 & 3 & 0.38 \\
Wish 1.8cc & 8703237190 & - & - & 870321420 & 1 & 0.13 & 1 & 0.13 \\
Wish 1.8cc & 8703237190 & - & - & 870323971 & 6 & 0.75 & 6 & 0.75 \\
Wish 1.8cc & 8703237190 & - & - & 870323521 & 6 & 0.75 & 6 & 0.75 \\
Wish 1.8cc & 8703237190 & - & - & 870321909 & 1 & 0.13 & 1 & 0.13 \\
Wish 1.8cc & 8703237190 & - & - & 870322909 & 1 & 0.13 & 1 & 0.13 \\
Wish 1.8cc & 8703237190 & - & - & 870323531 & 1 & 0.13 & 1 & 0.13 \\
Wish 2.0cc & 8703237290 & 11 & 1.90 & 870323729 & - & - & 11 & 1.38 \\
Wish 2.0cc & 8703237290 & - & - & 870323992 & 5 & 0.63 & 5 & 0.63 \\
\hline TOTAL & - & 572 & 72.22 & - & 223 & 28.05 & 795 & 100.00 \\
\hline
\end{tabular}

Based on the finding, $28.05 \%$ are considered as inaccurate or false tariff codes which are supposed not to be found in the CIS database. This weakness means that the CIS is not working properly in line with the current laws of Custom Duty Orders 2017. The effect of these weaknesses on auditing and tax calculation is vast since the software could be manipulated to enter false codes by company agents or by incompetent and corrupt Customs officials to get a low rate of tax and excise duties.

\section{b. Vehicles first date registration and CIF value}

According to the Malaysian Trade Classification and Customs Duties Order 2017, all prefabricated cars imported to this country must have a record of the first date of registration after being manufactured in their origin country. The year of manufacture and the date of 
MANAGEMENT SCIENCES

Vol. 11, No. 3, 2021, E-ISSN: 2225-8329 @ 2021 HRMARS

first registration is important as it determines the CIF value, and later tax rate to be paid to Customs department. Without this information, Customs officials cannot set up the correct CIF value and tax rate to be paid by agents. In Table 1.1, our analysis found that $80.63 \%$ or 641 output samples do not declare the first date of the vehicle registration in their origin country and only $19.37 \%$ were found declared. This shows that many vehicles brought in do not have exact information about true age and the records as used vehicles in the origin country. Thus, CIF value and tax rate will deteriorate if the calculation only assumes that all vehicles are registered by the local authority 6 months after being manufactured.

Table 1.1 - Declaration of the first date of vehicles registration $(n=795)$

\begin{tabular}{|c|c|c|c|c|c|c|}
\hline \multirow{2}{*}{ Case Category } & \multicolumn{5}{|c|}{ Declaration made } & \multirow{2}{*}{$\begin{array}{r}\text { Total } \\
\text { Per cent }\end{array}$} \\
\hline & Yes & $\begin{array}{l}\text { Per } \\
\text { cent }\end{array}$ & No & Per cent & Frequency & \\
\hline $\begin{array}{l}\text { First-date of the vehicle } \\
\text { registration in the origin } \\
\text { country }\end{array}$ & 154 & 19.37 & 641 & 80.63 & 795 & 100 \\
\hline
\end{tabular}

Due to negative findings, we have taken an initiative to checks the age of cars, years of manufacturing and other details including the first date of registration records via the Toyota's manufacturer official site at www.toyodiy.com. This was done by inputting Vehicles Identification Numbers (VIN - i.e., chassis number) in the search column provided on the site. The site has displayed all the records of the car such as years made, the first date of registration, cylinder capacity, seating capacity, engine number and other details. From there, we can make a comparison to find the identity for every car. Based on the thorough checks of 795 samples, we found that only $1.38 \%$ of output data in CIS are declared with the correct information, thus have true CIF value, while $98.62 \%$ were considered to have false or wrong CIF values (see Table 1.2).

Table 1.2 - Declaration of CIF value $(n=795)$

\begin{tabular}{lcccccc}
\hline & \multicolumn{5}{c}{ Declaration made } & Total \\
\cline { 2 - 7 } Case Category & Yes & Per & No & Per cent & Frequency & Per cent \\
\hline $\begin{array}{l}\text { CIF declared according to } \\
\text { custom Duties Order (2017) }\end{array}$ & 11 & 1.38 & 784 & 98.62 & 795 & 100 \\
\hline
\end{tabular}

The above finding shows that most output data generated from $\mathrm{CIS}$ is not compliant with Customs legal requirements in terms of the real CIF value declaration. However, the declaration forms have been accepted and proceeded to the next level and most of the vehicles are released later. This indicates a high risk of integrity breach in the tax administration system because $\mathrm{CIS}$ is accepting incorrect data value for processing that open doors for corrupt practices among Customs officials and agents.

\section{c. Imposed Tax Rate}

An analysis of 795 samples found that no mistake on the import duty (30\%) and the GST (6\%) tax rate charged to the importers. However, as for the excise duty rate, it was found that 3 samples are given a wrong duty rate while the remaining 792 samples were given the correct excise duty rate. As shown in Table 1.3, there are 2 cases $(0.25 \%)$ where the wrong excise 
INTERNATIONAL JOURNAL OF ACADEMIC RESEARCH IN ACCOUNTING, FINANCE AND

MANAGEMENT SCIENCES

Vol. 11, No. 3, 2021, E-ISSN: 2225-8329 @ 2021 HRMARS

duty rate of $65 \%$ was charged for Toyota Wish $2.0 \mathrm{cc}$ models whereas the actual rate was $75 \%$. In another case, there is one sample (0.13\%) that has been charged with a very low rate of excise duty of $39 \%$ for the Toyota Wish $1.8 \mathrm{cc}$ whereas the actual rate is $65 \%$.

Table 1.3 - Output of tax rate imposed to $1.8 \mathrm{cc}$ and $2.0 \mathrm{cc}$ vehicles under The Malaysian Trade Classification and Customs Duties Order 2017 and GST Act $2014(\mathrm{n}=795)$

\begin{tabular}{|c|c|c|c|c|c|c|c|c|c|c|}
\hline \multirow[t]{3}{*}{ Tax Categories } & \multicolumn{4}{|c|}{ Wish $1.8 \mathrm{cc}$} & \multicolumn{4}{|c|}{ Wish $2.0 \mathrm{cc}$} & \multicolumn{2}{|c|}{ Total } \\
\hline & \multicolumn{2}{|c|}{ True } & \multicolumn{2}{|c|}{ False } & \multicolumn{2}{|c|}{ True } & \multicolumn{2}{|c|}{ False } & \multirow{2}{*}{$\begin{array}{c}\text { Fre } \\
\mathrm{q}\end{array}$} & \multirow{2}{*}{ Percent } \\
\hline & Freq & $\%$ & $\begin{array}{c}\text { Fre } \\
\mathrm{q}\end{array}$ & $\%$ & Freq & $\%$ & $\begin{array}{c}\text { Fre } \\
\mathrm{q}\end{array}$ & $\%$ & & \\
\hline Import Duty* & 786 & 98.87 & - & - & 9 & $\begin{array}{c}1.1 \\
3\end{array}$ & - & - & 795 & 100 \\
\hline Excise Duty** & 775 & 97.48 & 1 & 0.13 & 17 & $\begin{array}{c}2.1 \\
4\end{array}$ & 2 & 0.25 & 795 & 100 \\
\hline GST $* * *$ & 776 & 97.48 & - & - & 19 & $\begin{array}{c}2.3 \\
9\end{array}$ & - & - & 795 & 100 \\
\hline
\end{tabular}

*Fix rate of 30\% import duty imposed according to Malaysian Trade Classification and Customs Duties Order 2017, cannot be manipulated.

**Fix Rate of Excise Duty Tax according to Malaysian Trade Classification and Customs Duties Order 2017 (65\% imposed for 18.cc and 75\% for 2.0 cc, cannot be manipulated). ***Fix rate 6\% GST imposed according to Goods and Services Tax (GST) Act 2014, cannot be manipulated.

\section{d. Physical checks on vehicles}

Section 68 of Customs Act 1967 provide a Senior Customs Officer to give an order for the inspection of imported or exported goods within the main Customs Control together with the presence of an agent. The compliance of physical inspection is also subject to fulfil under the Customs Standing Order No.61 (Import Procedure). In Table 1.4, our analysis shows that all samples of prefabricated cars brought in were not inspected by Customs officials in duties based on the null records of output data which indicates that no inspections were made by any officials even though a total of 423 (53.21\%) k-1 forms were ordered to be checked by Customs Assessing Officers via CIS.

Table 1.4- Output of Vehicles Physical Check

\begin{tabular}{ccc}
\hline Physical Examination & Frequency & Per cent \\
\hline Yes & - & - \\
No & 795 & 100 \\
\hline Total & 795 & 100 \\
\hline
\end{tabular}

The above finding means that the Customs Assessing Officer can be deemed not to have complied with Customs Standing Order No.61 (Import Procedure, para 3.6 and 3.7) in ensuring a thorough inspection to be made for all of Customs goods. Without inspection, the information about prefabricated cars such as the correct chassis number as well as the year of registration and other information cannot be determined, thus any kind of approval is deemed to be invalid or arbitrary. 
MANAGEMENT SCIENCES

Vol. 11, No. 3, 2021, E-ISSN: 2225-8329 @ 2021 HRMARS

e. Approved Permit (AP)

According to the Customs Act 1967, all imported vehicles without valid AP cannot be released from Customs control until the conditions have complied. An analysis of AP compliance in Table 1.5, however, show that $73.21 \%$ of the data samples do not have approval permit record and classified as Record Not Found (RNF) while 7.05\% have expired and only $19.75 \%$ are valid.

Table 1.5 - Approval Permit conformity to Act 2014

\begin{tabular}{lcc}
\hline Classification & $\begin{array}{c}\text { Frequenci } \\
\text { es }\end{array}$ & Percentage \\
\hline Record Not Found (RNF) & 582 & 73.21 \\
Valid & 157 & 19.75 \\
Expired & 56 & 7.04 \\
\hline Total & 795 & 100 \\
\hline
\end{tabular}

Overall, the combination of RNF and expired APs accounted for $80.25 \%$ indicating that the AP requirements have not been properly complied by most clients, but the automation system still accepts and process insufficient K-1 digital forms. The weaknesses of CIS that allow the entry of RNF and expiring AP for clearance process and approvals are inconsistent with the protocols under the Customs Act 1967 and related regulations relating to AP Import Guidelines.

\section{Conclusion and Recommendation}

Digitalization of customs duties and tariffs is a form of e-governance that aims to eliminate personal advantages and connections, as well as the influence of bribes from the process of paying tariffs and duties. (Inaki, 2014). However, the advantages of the CIS in faster processing of electronic documents and Customs clearance activities may not help in reducing the issues of integrity and corrupt practices among users, particularly the Customs agents and officials in duties. Based on the analysis, it is found that many output data generated from CIS are inconsistent with the requirements under the current Customs laws and circulars such as the Customs Assessment Rules 1993; Customs Duty Orders (Customs Duties 2017) and Excise Duties (2017); Customs Act 1967 and other related circulars (e.g., AP Import Guidelines and Vehicle inspection rules). These inconsistencies are aptly termed by UNECE-TFIG (2020) as "insufficient Customs Automation" that needs much improvement.

The main disadvantage of CIS is the design of the software itself which is found to permit clients or Customs officials to input incorrect, inaccurate, or incomplete information in the digital k-1 forms. For example, inaccurate coding for vehicles tariff code has been found in the CIS output data where $28.05 \%$ are considered as false tariff code. In addition, $80.63 \%$ of samples are not declared vehicles first date registration in the origin country, while $98.62 \%$ were considered to have false or wrong CIF values. CIS also failed to capture or record detailed vehicles year's made, seating capacity and the engine type as needed by K-1 form. The data output also shows that there are $3 \%$ of samples charged with an inaccurate excise duty rate for different types of Toyota's models. While, in the physical inspection records, the data showed that $100 \%$ of vehicles brought in were not marked as inspected via CIS. For AP records, findings show that $73.21 \%$ of samples do not have approved permits and are classified as Record Not Found (RNF) and 7.05\% have expired AP. This evidence shows that $\mathrm{CIS}$ is a weak software and can be manipulated by the parties involved in the transaction process, either Customs officials or company agents. 
MANAGEMENT SCIENCES

Vol. 11, No. 3, 2021, E-ISSN: 2225-8329 @ 2021 HRMARS

The weaknesses of CIS will not help the Customs department to positively improve audit findings regarding the poor quality of declaration forms and the issues of surplus and shortfall of tax collection as reported by Auditor's General Report as discussed earlier in this article. As a semi-digital automation system, CIS does not integrate itself with multiple other government agencies (OGA), PIAs (permit Issuing Agencies) and other related bodies which also contribute to the failure to record, review, and validate transaction information quickly and correctly, such as the information regarding approval permit and tax setting.

For the improvement, it is suggested that CIS must be updated, and the Customs risk management analysis focusing on the context establishment, identify risks, risks asses and prioritization, and addressing risks must be done to CIS environment. Risk management requires constant monitoring and review of the systems particularly the instruments and protocols used to eliminate false-negative as well as false-positive risks.

The CIS software must be able to prevent or block any incorrect, incomplete, and blank data entry into the system and must be able to warn both clients and Customs officials in the transaction process. The parameter set in the CIS must also be consistent and synchronized to the current development of Customs laws and circulars, and only specific data formats are allowed in the system. For example, to avoid CIS from recording inaccurate or false data for vehicles tariff-code, the specific parameter of the tariff-code data format must be set and automatically activated in the CIS. By enabling this function, the CIS must be able to reject and give a warning to the clients or officials if the information does not meet the codes set in the system. The same function must be done to all K-1 digital forms such as for inputting of vehicles registration date, year of manufacture, VIN, and others. The CIS must also be constructed to rejecting any data submission into the next levels of processing if the information is found inaccurate, incomplete, or blank. For example, without confirmation signs in the columns related to physical checks on vehicles by the officials on duty, the Customs assessor officer must not be able to proceed with the declaration or clearance to the next levels. To this end, the CIS itself needs many improvements including the divisional of tasks among officials. Apart from this, an education to CIS's customers especially to the importers and company agents must be carried out precisely.

\section{Acknowledgements}

The writing of this article is the based-on research data funded by The National University of Malaysia (UKM). Project Title - Analyzing the risk of integrity and leakage of government tax revenue for prefabricated imported vehicles through CIS databank 2017. Research Code SK2019-014.

\section{References}

Acconcia, A., D'Amato, M., \& Martina, R. (2003). Tax Evasion and Corruption in Tax Administration. Public Economics, paper 0310001. Germany: University Library of Munich.

Aman, A., Al-Shbail, T. A., \& Mohammed, Z. (2013). Enhancing Public Organizations Accountability through E-Government Systems. International Journal of Conceptions on Management and Social Science 1(1): 15-21.

Aman, A., Al-Shabil, T., Mohamed, Z., \& Auzair, A. (2016). E-Single window implementation: a case of Jordan Customs Department. International Journal of West Asian Studies, 4363. 
MANAGEMENT SCIENCES

Vol. 11, No. 3, 2021, E-ISSN: 2225-8329 ๔ 2021 HRMARS

Angsor, S., \& Yusof, M. M., (2019). Practising and Factors Influencing the Effective Implementation of Strategic Information Systems Planning in Public. Jurnal Pengurusan, 56 (2019), 95 - 106. https://doi.org/10.17576/pengurusan-2019-56-09

Alm, J., \& Torgler, B. (2011). Do Ethics Matter? Tax Compliance and Morality. Journal of Business Ethics, 101(4): 635-651.

Alon, A., \& Hageman, A. M. (2013). The Impact of Corruption on Firm Tax Compliance in Transition Economies: Whom Do You Trust? Journal of Business Ethics, 116(3): 479-494.

Arlyn, A. S. (2019). Data is power: Using Analytics for Customs audit. https://www.sgv.ph/csuite/data-is-power-using-analytics-for-a-customs-audit.

Crotty, J. (2010). Practical Measures to Promote Integrity in Customs Administration. Paper presented at the Eright International Anti-Corruption Conference. Prague, Chezch Republic, September 7-11.

Customs Act. (1967). Kuala Lumpur: Percetakan Nasional Malaysia Berhad.

Customs Assessment Rules 1993. (2019). Kuala Lumpur: Percetakan Nasional Malaysia Berhad.

Customs Duty Order. (2017). Kuala Lumpur: Percetakan Nasional Malaysia Berhad.

Escobari, D. (2011). Imperfect detection of tax evasion in a corrupt tax administration. MPRA Paper 39198. https://ideas.repec.org/p/pra/mprapa/39198.html

Ferreira, C., Engelschalk, M., \& Mayville, W. (2007). The challenge of combating corruption in customs administrations. In The many faces of corruption: Tracking vulnerabilities at the sector level., edited by J. E. Campos \& S. Pradhan (eds.). Washington, D.C: World Bank.

Fjeldstad, O. (2005). Revenue Administration and Corruption. Utstein Anti-Corruption Resource Centre, Chr. Michaelson Institute, Bergen, Norway. https://www.cmi.no/publications/2558-revenue-administration-and-corruption

Goods and Services Tax. (2014). Kuala Lumpur: Percetakan Nasional Malaysia Berhad.

Iñaki, A. A. (2014). Corruption in Tax And Customs Authorities. Anti-Corruption Helpdesk: Providing on Demand Research to Help Fight Corruption. Transparency International, 13 November 2014, p.p 1-14.

International Trade Centre - ITC. (2018). Faster customs, faster trade: Using technology for trade facilitation. ITC, Geneva

Ismail, R. (2019). Pengetahuan, Pematuhan dan Akauntabiliti Pegawai Penaksir Kastam Serta Implikasinya Ke Atas Ketirisan Hasil Cukai Kenderaan Import. Tesis ljazah Sarjana Sains Sosial (Pengajian Rasuah). Fakulti Sains Sosial dan Kemanusiaan, UKM Bangi.

Jacentha, N. M., \& Dalbir, S. (2020). Towards Data Privacy and Security Framework in Big Data Governance. International Journal of Software Engineering \& Computer Systems (IJSECS) ISSN: 2289-8522 e-ISSN: 2180-0650 Vol. 6, Issue 1, 41-51. https://doi.org/10.15282/ijsecs.6.1.2020.5.0068

Keen, M. (2003). Changing Customs Challenges and Strategies for the Reform of Customs Administration. Washington D.C.: International Monetary Fund.

Laporan Ketua Audit Negara (Siri 3). (2014). Laporan Maklum Balas Ke Atas Isu-Isu Utama Dalam Laporan Ketua Audit Negara Mengenai Penyata Kewangan dan Pengurusan Kewangan Tahun 2014 dan Aktiviti Kementerian / Jabatan Serta Pengurusan Syarikat Kerajaan Persekutuan dan Aktiviti Badan Berkanun Persekutuan Serta Pengurusan Syarikat Subsidiari. Putrajaya, Kementerian Kewangan Malaysia. 
MANAGEMENT SCIENCES

Vol. 11, No. 3, 2021, E-ISSN: 2225-8329 ๔ 2021 HRMARS

McLinden, G., \& Durrani, A.Z. (2005). Corruption in Customs. World Customs Journal, Vol. 7(2), September 2013. https://worldcustomsjournal.org/archive/volume-7-number-2september-2013/

National Automotive Policy 2020. (2020). ISBN 978-967-13593-8-9. https://www.miti.gov.my/miti/resources/NAP\%202020/NAP2020_Booklet.pdf

OECD. (2005). The Role of Automati Facilitation, OECD Trade Policy Papers, No Publishing, Paris. http://dx.doi.org/10.1787/841420380004.

Pashev, K. (2005). Corruption and Tax Compliance: Challenges to Tax Policy and Administration. Centre for the Study of Democracy, Sofia, Bulgaria.

Purohit, M. C. (2007). Corruption in Tax Administration. In Anwar Shah (ed.) (2007). Perfomance Accountability and Combating Corruption. Public sector governans and Accountability Series. World Bank: Washington DC

Razmerita, L., \& Bjørn-Andersen, N. (2007). Towards Ubiquitous e-Custom Services. IEEE/WIC/ACM International Conference on Web Intelligence. https:10.1109/WI.2007.148

Royal Malaysian Custom Department (RMCD). (2015). Ucapan sempena Exit Conference U Customs: The Way Forward. http://www.customs.gov.my/en/Pages/pi_ecuc.aspx

Royal Malaysian Custom Department (RMCD). (2017). uCustoms User Manual. Phase 9 - Ship Clearance (External User). 6th November 2017/Issue 1.2

Royal Malaysian Custom Department (RMCD). (2019). Implementation of Pilot Live uCustoms in Westport, Port Klang. uCustoms Latest News \& Announcement - Implementation of Pilot Live uCustoms in...

Sani, M. S. (2019). Harian Metro. Sistem U-customs di pintu masuk utama negara. https://www.hmetro.com.my/mutakhir/2018/01/308503/sistem-u-customs-di-pintumasuk-utama-negara

United Nations - Trade Facilitation Implementation Guide (UNECE-TFIG). (2020). Online Access http://tfig.unece.org/contents/customs-automation.htm, 1 January 2020.

United Nations - Trade Facilitation Implementation Guide (UNECE-TFIG). (2021). https://tfig.itcilo.org/contents/customs-risk-management.html.

Wahdain, E., Baharudin, A. S., \& Ahmad, M. N. (2019). Big data analytics in The Malaysian Public Sector: the determinants of valuable insights. 3rd International Conference of Reliable Information and Communication Technology, 2018 (IRICT2018). DOI:10.1007/978-3-319-99007-1_14WCO. (2006). Revised KYOTO Convention. World Customs Organization, 3 February 2006, Brussel, Belgium.

World Bank. (2006). Reforming the regulatory procedures for import and export: Guide for Practitioners. (V. Mathur, Ed.) (p. 116). International Finance Corporation, 2121 Pennsylvania Avenue, N. W., Washington DC.

Zuleta, J. C., Leyton, A., \& Fanta, I. E. (2007). Combating corruption in revenue administration: The case of VAT refunds in Bolivia. In The many faces of corruption: Tracking vulnerabilities at the sector level. In Campos, J. E. \& Pradhan, S. (eds). Washington, D.C.: World Bank. 